\title{
ATRAVESSANDO OS PORTÕES: EDUCAÇÃO NOS TERREIROS OU O QUE A ESCOLA PODERIA APRENDER
}

\author{
THROUGH THE GATES: EDUCATION IN THE TERREIROS OR WHAT THE SCHOOL \\ COULD LEARN
}

A TRAVÉS DE LAS PUERTAS: EDUCACIÓN EN LOS TERREIROS O LO QUE LA ESCUELA PODRÍA APRENDER

\author{
Verônica Kimura \\ Universidade do Estado de Santa Catarina - Brasil \\ Geovana Mendonça Lunardi Mendes \\ Universidade do Estado de Santa Catarina - Brasil
}

\begin{abstract}
Resumo: Este artigo versa sobre os aspectos de uma educação emancipadora ligada às tradições de matrizes africanas, pensada aqui como a educação nos terreiros e as implicações desta com a educação escolar formal monocrática. Desnuda elementos específicos desta educação com base na tradição dos orixás, voduns e inkices e as apresenta enquanto possibilidades enunciativas de visões de mundo negadas e perseguidas durante todo o processo de formação da educação brasileira. Vislumbra um horizonte de alternativas para uma educação pluriétnica e pluriversal.
\end{abstract}

Palavras chave: Educação; Terreiros; Escola formal.

\begin{abstract}
This article deals with the aspects of an emancipatory education linked to the African matrix traditions, thought here as the education in the terreiros and the implications of this with the formal monocratic school education. It exposes specific elements of this education based on the tradition of orixás, voduns and inkices and presents them as enunciative possibilities of world views that are denied and pursued through all the process of formation of Brazilian education. It envisions a horizon of alternatives for multi-ethnic and multi-universal education.
\end{abstract}

Keywords: Education; Terreiros; Formal school.

Resumen: Este artículo trata los aspectos de una educación emancipadora ligada a las tradiciones de matrices africanas, pensada aquí como la educación en los terreiros y las implicaciones de ésta con la educación escolar formal monocrática. Expone elementos específicos de esta educación basados en la tradición de los orixás, vodunes e inkices y los presenta como posibilidades enunciativas de visiones del mundo que son negadas y perseguidas durante todo el proceso de formación de la educación brasileña. Visualiza un horizonte de alternativas para la educación multiétnica y multiuniversal.

Palabras clave: Educación; Terreiros; Escuela formal. 


\section{A Árvore do Esquecimento}

Conta-se que na costa do Benin, mais precisamente em Wuidá, onde se localizava um dos grandes portos de embarque dos escravizados, havia uma grande árvore, ao redor da qual essas pessoas, após uma caminhada noturna de cinco quilômetros, eram obrigadas a darem voltas - mulheres davam sete voltas e homens, nove voltas - supondo-se que, simbolicamente, esse ato as faria perder a memória deixando para trás sua identidade cultural, suas origens e seu passado. Arrancados de sua terra de origem, povos de diversas etnias do continente africano foram violentamente subjugados à cultura europeia e, separados de sua terra natal e de suas famílias, tiveram seus nomes trocados e sua complexidade cultural negada, neste processo que a história denominou como Diáspora Africana. (MOREIRA; PERETI, 2020).

Evoco esta imagem da Árvore do Esquecimento para pensar nas inúmeras formas que o culto aos Orixás assumiu nas Américas, traçando uma marca na identidade cultural do povo brasileiro como uma tradição viva, presente em nossa produção musical, filosofias de vida, vestimentas, culinária, nosso calendário festivo, entre outras incontáveis manifestações de nossa cultura. Estudar as Tradições dos Orixás implica, em primeira instância, (re)conhecer um continente africano que foi fragmentado pelo projeto de colonização para, em seguida, procurar entender que as diferentes reelaborações no contexto da diáspora forjaram as comunidades de terreiro como um dos principais espaços de resistência para a população negra.

A tentativa de aprender sobre os processos que constituem a educação nos terreiros perpassa a obra de inúmeros pesquisadores que empreenderam esforços no sentido de contar, a partir de diferentes perspectivas, um pouco da história destes grupos subalternizado. Nosso objetivo aqui é apresentar algumas das particularidades desta educação identificadas nas contribuições de pesquisas já realizadas e de um corpo de autores que tem contribuído com nossas reflexões. Procuraremos situar em que contexto essas comunidades litúrgicas se formaram no Brasil, forjadas a partir de características multidimensionais que articulavam aspectos políticos, étnicos, territoriais, linguísticos, ancestrais e religiosos. Nesse caminho, traçaremos um diálogo entre a Educação nos terreiros e o espaço escolar, trazendo reflexões que possam tensionar a relação desses universos distintos.

A partilha que realizamos nesse texto, decorre dos estudos que temos desenvolvido em nosso grupo de pesquisa Observatório de Políticas Curriculares e Educação Inclusiva 
(OPEN), vinculado ao Laboratório Observatório de Práticas Escolares ${ }^{1}$ (OPE) e também da pesquisa realizada no âmbito do doutorado, denominada "Quem é de Axé, diz que é! A educação nas comunidades de tradições de matrizes africanas".

Realizamos uma pesquisa exploratória nos terreiros no período de (apontar) e socializamos aqui parte das impressões colhidas, bem como o aprofundamento teórico que norteou o estudo.

\section{Formação dos Egbé}

O tráfico de escravizados para o Brasil teve inúmeras motivações históricas, políticas, culturais e econômicas compondo parte de um projeto indispensável ao desenvolvimento da economia agrícola e mineral da colônia e ao lucro de Portugal. Durante três séculos de tráfico transatlântico e de próspero comércio, a presença de diferentes etnias africanas se reconfigurava no país. Contrariando o projeto colonial (e a árvore do esquecimento), essa população preservou, manteve e reelaborou grande parte de suas culturas de origem, em diferentes graus de aculturação, dependendo de maior ou menor retenção dos modelos e raízes africanas e das circunstâncias sócio históricas das diversas regiões onde se estabeleceram os vários grupos étnicos.

A partir do estabelecimento de laços culturais estes povos agruparam-se no espaço físico brasileiro de acordo com semelhanças que guardavam entre si e ajustes mútuos. ${ }^{2}$ Conforme aponta Mortari (2015), embora a denominação Nagô tenha sido utilizada no contexto diaspórico para denominar os povos de língua ioruba, que era formado por grupos de diversas procedências, as articulações sociais desencadeadas neste contexto permitiram que tais grupos se readaptassem através de um processo de transculturação que viabilizou a reestruturação e a reinvenção de novas identidades no território brasileiro:

A reinvenção das identidades dos africanos iniciava-se já nas Áfricas quando este recebia um nome de nação e era transformado em africano pela lógica do tráfico atlântico. Inseridos num contexto escravista, marcado pela violência, esses homens e mulheres, provenientes de diversas regiões da África, portadores de valores e culturas diversas, reinventaram suas identidades e criaram, dentro das possibilidades existentes, suas vidas. (MORTARI, 2015, p. 144).

\footnotetext{
${ }^{1}$ O OPE, vincula-se ao Programa de Pós-graduação em Educação da UDESC (Universidade do Estado de Santa Catarina).

${ }^{2}$ Para esclarecimentos detalhados sobre o agrupamento do grande grupo Nagô ver Juana Elbein dos Santos - Os Nagô e a Morte (1975).
} 
É possível que neste processo de reinvenção de identidades e reelaborações de suas culturas de origem, os contatos estabelecidos entre esses diversos grupos étnicos, reunidos em torno das semelhanças de seus costumes e, sobretudo, de sua origem mítica e das suas formas de se relacionar com o sagrado tenham sido determinantes na formação dos terreiros na costa brasileira. São inúmeros os indícios de práticas sagradas ainda no período escravista, conforme relatos compartilhados por pesquisadores e por autoridades das Tradições dos Orixás. Numa delas, por exemplo, conta-se que os negros escravizados adotavam imagens de santos da igreja católica e que, por uma associação de atributos entre os seus orixás e determinados santos católicos, ocultavam no interior de tais imagens os Okuta - pedras que representavam o assentamento de cada orixá, o que possibilitava que seus cultos transcorressem sem maiores problemas aos olhos de "seus senhores" 3 .

Contudo, a organização das comunidades litúrgicas (os egbé), ocorre a partir do século XIX, formando o que conhecemos hoje como "terreiros", espaços de implantação e reformulação de complexos culturais africanos, no qual se mantém o culto aos Orixás e aos ancestrais (Egun). De acordo com Santos (1975),

Essas associações acham-se instaladas em roças, que ocupam um determinado terreno, o "terreiro", termo que acabou sendo sinônimo da associação e do lugar onde se pratica a religião tradicional africana. Esses "terreiros" constituem verdadeiras comunidades que apresentam características especiais. Uma parte dos membros do "terreiro" habita no local ou nos arredores do mesmo, formando às vezes um bairro, um arraial ou um povoado. [...]O vínculo que se estabelece entre os membros da comunidade não está em função de que eles habitem num espaço preciso: os limites da sociedade egbé não coincidem com os limites físicos do "terreiro". [...] Os membros do egbé circulam, deslocam-se, trabalham têm vínculos com a sociedade global, mas constituem uma comunidade "flutuante", que concentra e expressa sua própria estrutura nos "terreiros". (SANTOS, 1975, p. 33).

A pluralidade dessas associações no território brasileiro está intimamente relacionada com a complexidade das relações interétnicas e das mobilidades interculturais transcorridas desde o contexto diaspórico. Conforme assinala Parés (2007), a "fluidez interétnica teria sido um fator constante e até imprescindível, na gênese e continuidade do candomblé." (p. 150). Contudo vale ressaltar, que através e no interior dessas comunidades "religiosas" foram mantidas as peculiaridades dos grupos étnicos diversos que originaram as atualmente conhecidas "nações de candomblé". Dito de outro modo:

\footnotetext{
${ }^{3}$ Relatado pelo Babalorixá Guaraci Fagundes e Egbomi Jayro Pereira de Jesus, Florianópolis, 2016. Entre os anos 2016 e 2017 houveram inúmeras conversas entre esta pesquisadora e o teólogo Jayro Pereira de Jesus, além de situações rituais onde os mais velhos orientam os mais novos a respeito de temas diversos nas tradições aqui estudadas. Ao longo do presente texto o referido teólogo será mencionado em outros momentos, acerca de assuntos que decorreram deste período da pesquisa.
} 
As distinções entre diversas nações de candomblé, apesar do silêncio documental, seguramente persistiram no seio de certas congregações religiosas, como acontece até hoje. Com o progressivo falecimento dos líderes africanos na segunda metade do século, os seus descendentes crioulos, após herdar a liderança dessas congregações, continuaram a manter as identidades de nação com base nessas práticas rituais. Portanto, embora a heterogeneidade étnico-racial dos participantes dos candomblés tivesse crescido ao longo do século, a identidade das nações africanas ficou ancorada em certas características de tradições religiosas diferenciadas. (PARÉS, 2007, p. 150).

Outro aspecto assinalado pelo sociólogo Muniz Sodré (1988) refere-se à necessidade de reterritorialização, característica inerente a uma cultura de exílio. O autor relata que o banzo $^{4}$ fora responsável por inúmeros suicídios e que o ato "comer terra", muito praticado em tempos de cativeiro, relacionava-se, simbolicamente, com a falta da terra natal. A questão da espacialização nos terreiros é problematizada por Sodré como uma forma de continuidade que possibilita uma espécie de metáfora, um único espaço que agrega o culto a Orixás provenientes de diferentes regiões africanas. Aponta como referência a organização física do Ilê Axé Opô Afonjá (Salvador-BA), terreiro no qual ocupa o cargo de Obá de Xangô ${ }^{5}$, composta por um salão principal com pequenas casas dispostas em seu entorno que representam, cada casa, diferentes Orixás cultuados originalmente em uma determinada região e que ali compartilham o mesmo espaço sagrado reconstituindo, simbolicamente, o continente africano.

Tal organização é comum a inúmeros terreiros de Tradições de Matriz Africana, sendo que a estruturação destes espaços sagrados tem se reelaborado continuamente para atender às novas demandas socioculturais e políticas. O teólogo Jayro Pereira de Jesus relata que ao visitar um terreiro no interior do Rio de Janeiro deparou-se com uma estrutura física similar a uma cidade. Em torno do salão principal estavam dispostas as casas dos orixás como residências independentes, cada uma delas abrigando, além do assentamento do seu orixá, um projeto sociocultural relacionado aos atributos deste orixá/morador. Citou como

\footnotetext{
4 "Das doenças crônicas... uma, e das principais moléstias crônicas, que sofrem os escravos, a qual pelo decurso do tempo os leva à sepultura, vem a ser o banzo. O banzo é um ressentimento entranhado por qualquer princípio, como por exemplo: a saudade dos seus, e da sua pátria; o amor devido a alguém; à ingratidão, e aleivosia, que outro lhe fizera; a cogitação profunda sobre a perda da liberdade; a meditação continuada da aspereza com que os tratam; o mesmo mau trato, que suportam; e tudo aquilo que pode melancolizar. É uma paixão da alma, a que se entregam, que só é extinta com a morte: por isso disse que os pretos africanos eram extremosos, fiéis, resolutos, constantíssimos, e susceptíveis no último extremo do amor e do ódio (...). Este mesmo banzo por vezes observei no Brasil, que matara a muitos escravos; porém sempre por efeitos do ressentimento do rigor, com que os tratavam os seus senhores." (MENDES, Luiz Antonio de Oliveira. Memória a respeito dos escravos e tráfico da escravatura entre a Costa d'África e o Brazil, apresentada à Real Academia de Ciências de Lisboa, 1793. Porto, Publicações Escorpião, 1977. Pag. 61-62). Disponível em https://pt.wikipedia.org/wiki/Banzo.

${ }^{5}$ Título honorífico do Candomblé criado no Axé Opó Afonjá por Mãe Aninha em 1936, esses títulos honoríficos de doze Obás de Xangô, reis ou ministros da região de Oyo, foram concedidos aos amigos e protetores do Terreiro. Corpo de Obás - Ministros de Xangô. Aos Obás foi entregue o destino civil do Terreiro.

Disponível em https://pt.wikipedia.org/wiki/Obá_de_Xangô
} 
exemplo a casa de Iansã que possuía uma cozinha e uma sala onde acontecia, na ocasião de sua visita, uma reunião referente a um projeto voltado para as mulheres empreendedoras da comunidade.

Tal relato assinala um espaço compartilhado entre tradição e inovação numa complexa interação repleta de significados. Pensamos que buscar compreender as especificidades da educação no contexto dos terreiros pressupõe transitar entre fluxos simultâneos de continuidade e descontinuidade onde, entre valores que se mantém e mudanças que vem sendo introduzidas ao longo da história, seja possível perceber modos de aprender, ensinar e conceber o mundo que vem sendo compostas no interior dessas comunidades.

\section{Educação nos Terreiros: atravessando os portões}

Antes de lançarmos um olhar mais atento ao aprendizado nas comunidades de terreiro gostaríamos de engendrar algumas reflexões quanto ao paradigma de educação formal que, segundo afirma o sociólogo Muniz Sodré (2012), continua baseado num modelo clerical e prisional, herança da colonização religiosa no país. De acordo com o autor continuamos reproduzindo tal modelo de educação religiosa desde a disposição física do espaço escolar até a dimensão pedagógica, referindo-se à figura do professor como aquele que detém todo o conhecimento. Acredita que a reinvenção da educação brasileira perpassaria um processo de descolonização, enfatizando a importância do processo de formação e valorização do professor que atuaria, então, como um iniciador ou como um mediador do conhecimento.

O espaço escolar formal funciona a partir de uma lógica temporal. Freitas (2016) chama atenção para o fato de que a forma escolar produz uma organização que privilegia a homogeneidade e a simultaneidade. O terreiro, por outro lado, opera a partir da lógica espacial. Sodré (1988) afirma que o pensamento do terreiro valoriza o espaço e a força produzindo uma organização que tem como primazia o contato e a corporeidade. Recorremos novamente às ideias de Sodré (2012) e Santos (2010) acreditando ser possível o exercício de pensarmos outras perspectivas educacionais que levassem em conta uma "horizontalização" de saberes diversos ou de uma "ecologia de saberes"

O reconhecimento da persistência do pensamento abissal é, assim, conditio si ne qua non para começar a pensar e agir para além dele. [...] $\mathrm{O}$ pensamento pós-abissal pode ser sumariado como um aprender com o Sul usando uma epistemologia do Sul. Confronta a monocultura da ciência moderna com uma ecologia de saberes. É uma ecologia, porque se baseia na pluralidade de conhecimentos heterogêneos (sendo um deles a ciência 
moderna) e em interações sustentáveis e dinâmicas entre eles sem comprometer a sua autonomia. A ecologia de saberes baseia-se na ideia de que o conhecimento é interconhecimento. (SANTOS, 2010, p. 44-45).

É importante assinalar que, mesmo atravessando a repressão imposta durante o processo colonial, povos de diferentes etnias organizaram-se em torno das semelhanças que guardavam entre si, formando comunidades de culto aos orixás, inkices e voduns, que reproduziam e reproduzem, ainda hoje, fragmentos de pequenas Áfricas. As roças de candomblé no Brasil conseguiram agrupar, por meio dos ajustes que foram estabelecendo-se entre povos, orixás que pertenciam a diferentes regiões africanas, a exemplo da nação ketu, do grupo nagô-iorubá, que cultua dezesseis orixás.

Como consequência do estabelecimento desses agrupamentos temos hoje, nesses espaços, a possibilidade de reconexão cosmológica e civilizatória com um conjunto de valores filosóficos, éticos e morais que desestabilizam a lógica capitalista vigente, colocando em xeque a hegemonia cultural europeia. Pensar a educação nesta perspectiva possibilita que vislumbremos uma educação brasileira contra hegemônica em todas as suas dimensões. Os valores educacionais reproduzidos nos terreiros partem de uma visão de mundo que tem como prerrogativa a "morte" do sujeito. O ser individual é submetido, por meio de um processo que culmina num rito iniciático, à integração de um coletivo que substitui a noção de família pequeno burguesa, ícone da sociedade capitalista.

Um conjunto de valores educacionais balizam a formação deste ser coletivo no seio das comunidades de terreiro e as reflexões aqui desenvolvidas procuram elencá-las de modo a torná-las conhecidas para educadores, acreditando-se naquilo que a escola formal tem a aprender e na possibilidade de uma educação transformadora. Essa emancipação perpassaria questões como a noção de coletividade, ancestralidade, intersubjetividade, territorialidade e temporalidade e, simbolicamente, ela é potencializada desde o momento que chegamos no Egbé, ao adentrarmos os portões dos terreiros pelo Brasil e pelas Américas onde as tradições dos orixás, voduns e inkices estão presentes.

A travessia dos portões do barracão de Candomblé representa, para as pessoas desta tradição, uma transposição de fronteiras. $\mathrm{O}$ ato de passar sobre a cabeça uma cuia contendo água limpa para, em seguida, "despachá-la" na rua, permite que adentremos a um mundo que entendemos como sagrado, deixando aquilo que é mundano para o lado de fora. A partir deste primeiro ato introdutório, uma vez que muitos outros se seguirão, damos o primeiro passo em direção à visão de mundo praticada neste contexto deixando para fora a vestimenta eurocêntrica que determina que somos seres individuais, com nossas profissões, formações, 
posições sociais, poder aquisitivo, relações e todas as inúmeras qualificações que nos determinam em nossa sociedade.

Entre o adentrar e o passar para o estado de pertença reside um mundo intermediário onde iniciamos os preparativos para realizarmos essa passagem completamente, através de um ato iniciático. Rompemos com as práticas ocidentais para nos alinharmos numa cosmovisão, cujas hierarquias sociais dão lugar a fala através da corporeidade. Não só as vestimentas são trocadas, mas um outro tipo de comunicação se estabelece a partir dos gestos, de olhares e de práticas rituais que são aprendidas por meio da vivência e pela absorção de outros valores cotidianos. Esta transposição de um mundo universal e ocidental a uma visão pluriversal africana leva em conta uma filosofia de mundo cuja ética e conceitos descrevem um corpo cosmológico que produz uma reorganização ontológica e epistemológica sobre a vida.

A fim de compreender de que forma esses valores culturais são transmitidos e absorvidos no contexto desta tradição, basta observarmos com olhos atentos: em dia de festa no barracão é comum um cenário é sempre alegre, mas de muita atenção, com muitos convidados chegando e se acomodando nos bancos dispostos para os visitantes ao redor do salão, o que nos espaços tradicionais chamamos de assistência. Os adultos trabalham ordenadamente, já com suas vestes rituais e muitas crianças permanecem brincando juntas, por cima dos bancos e cadeiras ou correndo pelo salão em torno do mastro central. Todas as tarefas são aprendidas cotidianamente a partir da vivência no barracão, além disso, a cronologia das atividades não obedece ao ritmo temporal produzido pelo Ocidente, o que significa dizer que o tempo marcado pelo relógio é substituído pelo tempo necessário para que essas atividades aconteçam. É a palavra, entoada ritmicamente que determina a cadência dos rituais (HAMPATÉ BÂ, 1980).

Ao soar do Adjárin, pela mão do Babalorisà, todos procuram suas posições dentro da ordenação ritual e, neste momento, as crianças separam-se e posicionam- se de acordo com sua idade iniciática. É idade iniciática que organiza todas as ações rituais dentro do terreiro. Além disso, as sociabilidades e as relações no interior dessas comunidades litúrgicas que caracterizam-se por ser rigorosamente hierárquicas são determinadas, de um modo geral, pela idade iniciática. Um exemplo dessa organização pode ser verificado na disposição física dos grupos. É comum que abyan (não iniciado) esteja conversando com abyan e realizando tarefas que são designadas a este grupo. Nos momentos rituais, embora o contexto seja coletivo, cada grupo está cuidadosamente separado entre si. A esse respeito, Caputo (2012) afirma que, 
A antiguidade iniciática é superior à idade civil. Por exemplo, se um adulto chega ao terreiro para começar a aprender a religião, uma criança pode perfeitamente ser responsável por lhe passar os ensinamentos. No terreiro de Mãe Palmira uma criança toma a benção de alguém mais velho da mesma forma que um adulto toma a benção à criança. As expressões são sempre 'Abença, meu pai' ou 'Abença, minha mãe'. (p. $72)$.

A antiguidade ou idade iniciática refere-se ao tempo que se tem no santo, o tempo desde o ritual de iniciação ou de feitura. Segundo o teólogo Jayro Pereira de Jesus na visão de mundo da tradição africana acredita-se que, até o momento da gestação, ainda no ventre materno, estamos ligados ao TODO e, no momento do nascimento, somos desconectados passando a seres individuais. $\mathrm{O}$ ato iniciático teria a função de nos religar, nos reconectar através do Axé, representando simbolicamente o renascimento para uma nova vida de dedicação e de culto ao Orixá. De acordo com Santos (1975) o Axé (força, poder, energia) representa o elemento mais importante no terreiro e para que o indivíduo o receba, precisa ser iniciado por meio de um ritual conduzido por palavras que têm poder de ação. Neste rito o Axé e o conhecimento são transmitidos, não exatamente em nível intelectual, mas pela transferência de um complexo simbólico composto por uma relação dinâmica que se dá a partir da corporeidade e do poder da palavra. A autora afirma que "a palavra faz parte de uma combinação de elementos de um processo dinâmico que transmite um poder de realização. Asè: que isto advenha" (SANTOS, 1975, p.46).

A palavra na tradição de matriz africana é um elemento vivo, seja em português ou ioruba, cantada ou falada, a palavra é condutora de processos de ensino e aprendizagem e carrega a transmissão dos costumes, orientações e encaminhamentos, sendo também a ponte entre passado, presente e futuro. Tomando como referência o Candomblé de Ketu, desenvolvido no Brasil pelo grupo nagô-iorubá, Beniste (1997) informa que a tradição dos orixás representa o elemento central na vida de seus praticantes e se expressa por meio de cânticos, mitos e provérbios, que compõem sua filosofia de vida:

Como não havia nenhuma forma de documento escrito no passado, tudo que foi preservado sobre suas divindades chegou até nós por palavras faladas, que passaram de geração a geração, constituindo-se o que se costumou chamar de TRADIÇÃO ORAL. E isso remonta ao continente africano. Essas tradições são os nossos únicos meios de se saber qualquer coisa de sua teogonia e cosmogonia, o que eles pensam e no que acreditam acerca das relações entre o CÉU e a TERRA (ÓRUN-AIYÉ). (BENISTE, 1997, p. 19 e 20).

Essa é uma característica fundamental que diferencia a educação dentro da tradição religiosa de matriz africana dos valores praticados em nossa sociedade ocidental, uma vez 
que temos a escrita como veículo principal de transmissão de conhecimento e o livro como seu maior ícone. Para ampliar nossa compreensão a respeito dessa relação entre o homem e a palavra na tradição africana, herdada por nós através da relação com a sacralidade e o culto aos orixás, compartilhamos do conhecimento de Amadou Hampaté Bâ (1980), acerca do pensamento do homem africano:

Nada prova a priori que a escrita resulta em um relato da realidade mais fidedigno do que o testemunho oral transmitido de geração a geração. [...] É, pois, nas sociedades orais que não apenas a função da memória é mais desenvolvida, mas também a ligação entre o homem e a Palavra é mais forte. Lá onde não existe a escrita, o homem está ligado à palavra que profere. Ele é a palavra e a palavra encerra um testemunho daquilo que ele é. [...] Nas tradições africanas - pelo menos nas que conheço e que dizem respeito a toda a região de savana ao sul do Saara - a palavra falada se empossava, além de um valor moral fundamental, de um caráter sagrado vinculado à sua origem divina e às forças ocultas nela depositadas. Agente mágico por excelência, grande vetor de "forças etéreas", não era utilizada sem prudência. (HAMPATÉ BÂ, 1980, p. 182).

Herança da dinâmica diaspórica, a oralidade descrita pelo autor nas tradições africanas permanece latente no interior das comunidades tradicionais de terreiro no Brasil, compondo uma complexa trama simbólica que agrega em si elementos corporais, gestos e movimentos, expressões faciais e palavras não ditas, comportamentos e atitudes que vão, aos poucos, revelando (ou ocultando) os segredos da tradição do culto aos Orixás.

Operando a partir de uma lógica espacial, própria do lugar, existe uma extrema valorização da proximidade e do contato. Isso não significa que não hajam os conflitos próprios da natureza humana, mas que os ensinamentos e a transmissão de valores se dão a partir da convivência, conforme enfatiza Wanda Machado ao relatar as palavras com as quais foi recepcionada em sua chegada ao Opô Afonjá:

Que vocês sejam bem-vindos à família de Xangô. Agora que vocês foram chamados para esta família, vamos ficando por aqui. É assim, a gente vai ficando, vai sentindo o cheiro do outro pra ver se a gente gosta, se é isto mesmo. Este foi um dos primeiros ensinamentos desta preceptora que sempre ouviu e entendeu as nossas dúvidas, nossos medos e ansiedades. Sentir o cheiro do outro. Isso nunca me saiu da cabeça. Pra sentir o cheiro do outro não é necessário nenhum movimento. Nem precisa dizer nada, é só olhar e escutar. É só ficar perto e escutar muito. Escutar é o melhor que se tem a fazer. Não precisa perguntar nada, porque todo saber chega na hora certa. Aqui ninguém fica ignorante, é só ficar perto dos mais velhos. (Ebome Detinha em depoimento a MACHADO, 2013, p. 119).

Para além da proximidade que permite sentir o cheiro e o hálito do outro, a questão da corporeidade é fundamental nestes espaços sagrados. O corpo está em primeiro plano. O pensamento atravessa o corpo. $\mathrm{O}$ corpo inscreve uma nova lógica no iniciado que evidencia- 
se desde a travessia dos portões. O corpo presente absorve conhecimentos, valores e um vasto repertório de movimentos que vão possibilitando contar a história do ser em si e de sua ancestralidade, servindo de veículo para as divindades.

O corpo, morada e receptáculo dos orixás, na dança ritual do candomblé não é composto por gesto individualizados, escolhidos pelo fiel, segundo sua livre criação e interpretação de movimento. Existe uma gestualidade inerente ao ritual, que é facilmente identificável, com características próprias e codificação sofisticada. Essa gestualidade pode ser entendida como um elaborado sistema de ações corporais desenvolvida ao longo dos tempos [...] "para construir um sistema mais ou menos coerente de maneiras de ser corporais" (PAVIS, 1999, p. 186). Esse conjunto de movimentos e intenções corporais foi desenvolvido para estabelecer uma significação dependente dos mitos do orixá que está incorporando, bem como da cosmologia do candomblé. (ZENICOLA, 2014, p. 92)

É importante também ressaltar o aspecto ambiental na educação dos terreiros. A relação do Candomblé e de seus adeptos com a natureza é de profundo respeito e reverência. A frase em iorubá: Kosí ewe, kosí Òrisá, sem folha não há Orixá, encerra a profundidade desta relação. As folhas estão presentes em todos os atos rituais praticados no candomblé e grande parte do "segredo" da tradição consiste no conhecimento do uso das folhas. Esta é uma relação de sacralidade com as plantas e com a natureza aparece em diversos trabalhos sobre este tema, conforme depoimento a seguir:

O candomblé vai contra essa lógica que hoje destrói o planeta. Nossa religião lida com os quatro elementos da natureza (fogo, terra, água e ar) e com os três reinos (vegetal, mineral e animal). São esses elementos integrados que formam o Asè, a força dinâmica que a tudo move e anima. Portanto, o candomblé é a religião mais ecológica que existe, porque só concebemos a nossa própria existência integrada à natureza. Yemojá é a energia das ondas do mar, das águas do mar. Òsun, das águas doces, dos rios, das cachoeiras. Òsáyin, dos vegetais, das folhas. Sàngó, dos trovões, do fogo. Yánsàn, do ar e da terra. Òsóòsì é o grande caçador. Quando uma criança começa a lidar com isso desde cedo, ela não apenas se sente parte da natureza, é mais que isso, ela entende que ela é a natureza. (Mãe Palmira em depoimento a CAPUTO, 2012, p. 76).

A fala da Iyalorixá Palmira descreve a associação de alguns Orixás a determinadas forças da natureza e, de acordo com a cosmovisão da tradição iorubana, o culto aos Orixás, em sua totalidade, baseia-se nessa relação com os quatro elementos da natureza. Uma descrição mais aprofundada sobre essa relação pode ser verificada no filme "Jardim das Folhas" e nos documentários "Casa de Santo" e "Atlântico Negro - Na Rota dos Orixás". 6

\footnotetext{
${ }^{6}$ Disponíveis no site You Tube.
} 
Outro aspecto relevante no âmbito dessas reflexões sobre a educação nos terreiros trata das relações pessoais e da noção de pertencimento ao grupo e de coletividade. Fundamentadas no princípio ético e filosófico UBUNTU, cuja máxima pode ser definida pela expressão "Eu sou, porque nós somos", a noção de coletividade sobrepõe-se ao individualismo experimentado na sociedade capitalista ocidental. A "morte do eu" que culmina no ato iniciático representa a conexão simultânea do indivíduo com seus ancestres, com sua divindade e com a coletividade à qual pertence. Segundo o filósofo sul-africano Mogobe Ramose, a comunidade é lógica e historicamente anterior ao indivíduo e, por isso, tem primazia sobre ele; a comunidade é uma "entidade dinâmica" composta por três esferas: a dos vivos, a dos mortos-vivos e a dos não-nascidos, e acrescenta:

Em um sentido estritamente tradicional ou, se preferir, religioso, ubuntu significa que nós só nos tornamos uma pessoa ao sermos introduzidos ou iniciados em uma tribo ou em um clã específicos. Nesse sentido, 'tornarse uma pessoa por meio de outras pessoas' implica em passar por vários estágios, cerimônias e rituais prescritos pela comunidade. Entretanto, em um sentido comum ou secular, ubuntu significa simplesmente compaixão, calor humano, compreensão, respeito, cuidado, partilha, humanitarismo ou, em uma só palavra, amor. (RAMOSE, 2010, p.5).

No contexto educacional dos terreiros cabe ressaltar que o sentido comunitário desestabiliza a noção de família conforme a vivenciamos em nossa sociedade. De um modo geral as crianças do barracão são todas nossas e tarefas como cuidar, alimentar, brincar, chamar à atenção são tarefas de todos os adultos, comumente realizadas por quem está disponível, independentemente dos pais estarem presentes ou não. Envoltos nesse ambiente, as crianças vão desenvolvendo, desde cedo, um sentido de partilha e absorvendo o significado do "nós".

Compreender estas lógicas distintas implica em imergir num pluriverso que desestrutura nossas noções imediatas de pessoa, as relações sociais que só existem em oposições binárias e suprimir as concepções dualistas do ocidente que só se sustentam a partir de dualismos do tipo alto/baixo, dentro/fora. Entender como funcionam os rituais não significa somente descrevê-los, conhecer de que forma funciona a força vital de um Orixá não é possível a partir de suas características. A compreensão se dá somente através da vivência e dos ensinamentos advindos dela por meio da oralidade e da corporeidade em que os sujeitos estão mergulhados.

\section{O que a Escola poderia aprender com a Educação nos Terreiros}


Procuramos aqui estabelecer um diálogo com as práticas educativas forjadas no interior das comunidades de terreiro, baseando-nos em elementos que foram vivenciados em nossa pesquisa de campo, num referencial teórico decolonial e na produção de pesquisadores que já sinalizaram anteriormente a possiblidade de se tecer novos horizontes para a escola contemporânea. Acreditamos que haja indícios de que as formas de se ensinar e se aprender em diferentes manifestações das tradições de matrizes africanas sugerem um tipo de educação igualitária pautada em elementos que demandariam a emergência de outra cultura escolar, como as noções de coletividade, ancestralidade, intersubjetividade, territorialidade e temporalidade.

Essa construção do ser coletivo no seio das comunidades pesquisadas salta aos olhos de quem quiser ver, estão latentes em inúmeras imagens captadas neste curto período de pesquisa exploratória ${ }^{7}$ : o jovem Douglas, menino criado como filho da Iyalorixá Jacila de Oxum, chega da escola, tira seu uniforme e toma seu banho de folhas antes de almoçar. A mesa já está posta, mas ele sai em direção às casas de santo para tomar benção aos orixás. Só então faz o seu prato, pede a benção de sua mãe adotiva e mãe de santo, pergunta se as outras crianças já almoçaram e divide o refrigerante que sobrou em três copos... A própria representação do transitar.

Nesse sentindo, pensar na educação dos terreiros como uma educação emancipadora aponta, não só a necessidade de se rever a noção do que é a Escola, mas evidencia as vozes dos sujeitos envolvidos, instituindo, geopoliticamente, sua forma de estar no mundo como sujeitos.

É um movimento de apontar caminhos para uma educação mais democrática, cuja premissa básica não prescinda da contribuição de distintos grupos étnicos que foram introduzidos no país versus uma educação monocrática de orientação europeia. É estabelecer parâmetros e critérios por meio dos pilares que sustentam filosofias de matrizes africanas

\footnotetext{
${ }^{7}$ É importante mencionar que esta pesquisa de campo foi atravessada pela pandemia decorrente do COVID 19 afetando os prazos e demandando uma série de ajustes nas formas como a pesquisa havia sendo realizada. Após um período inicial de corte e paralisação das atividades previstas, iniciou-se um processo de reelaboração frente às novas demandas impostas pela situação social, gerando a necessidade de novas negociações com o campo de pesquisa e com os sujeitos pesquisados. Um novo conjunto de ações foi sendo estruturado metodologicamente, de forma a não comprometer o resultado final da pesquisa, readequando-a as possibilidades que nos foram colocadas pela falta de perspectiva de um retorno à normalidade. Dentre essas ações destacamos os contatos com os sujeitos e com o campo pesquisado que passaram a ser feitos de forma virtual, por meio dos recursos disponíveis na mídia digital, as negociações com os sujeitos para a inclusão desta pesquisadora em grupos de WhatsApp que geralmente são reservados à participação de membros internos dos grupos pesquisados, o levantamento de uma nova base de dados para o campo de pesquisa que é público e disponibilizado por meio de vídeos publicados no YouTube e que exigem, por sua vez, ajustes no processo de análise e no conjunto de leituras.
} 
(territorialidade, ancestralidade coletividade, intersubjetividade, e temporalidade). É pensar um mundo de forma pluriétnica e pluriversal cujo ódio à diferença não sejam as bases sobre as quais se sustentam toda forma de preconceito e de discriminação racial. É propor novas empreitadas até então não vislumbradas e assumir novas epistemologias e ontologias que se apresentam como novas formas de se ver e pensar os sujeitos contra esse mundo criado na Modernidade.

Um mundo que nos afastem da violência cotidiana que assolam crianças, jovens e adolescentes e suas famílias, para que construamos relações de respeito e dar dignidade a todos àqueles que compõem o amplo espectro da cultura escolar brasileira, marcadamente racista e excludente. Mas acima de tudo, para que possamos ter o mínimo de chance de tentarmos ser aquilo que jamais experimentamos por conta do colonialismo: a possibilidade de existência com direito pleno e cidadania ampla através de uma educação emancipadora. Axé!

\section{REFERÊNCIAS}

BENISTE, José. Òrun Àiyé - O Encontro de Dois Mundos. Rio de Janeiro: Bertrand Brasil, 1997.

CAPUTO, Stela Guedes. Educação nos Terreiros e como a escola se relaciona com as crianças de candomblé. Rio de Janeiro: FAPERJ e Pallas, 2012.

FREITAS, Marcos Cesar de. O Aluno Incluído na Educação Básica. São Paulo: Editora Cortez, 2016..

HAMPATÉ BÂ, Amadou. Tradição Viva. In: KI-ZERBO (org). História da África Geral I. Metodologia e Pré-história da África. São Paulo: Ed. Ática/UNESCO, 1980.

MACHADO, Vanda. Pele da Cor da Noite. Salvador: EDUFBA, 2013.

MOREIRA, Rodrigo B. e PERETI, Emerson. A Árvore do Esquecimento e as Tentativas de Destruição da Memória Afrodiaspórica. In: Revista UNIABEU, v.13, n.33, 2020.

MORTARI, Claudia. Pensando a Diáspora Africana: algumas questões. In: MORTARI, Claudia (Org.) Introdução aos Estudos Africanos e da Diáspora. Florianópolis: DIOESC/UDESC, 2015.

PARÉS. Luis Nicolau. A Formação do Candomblé - História e ritual da nação Jêje na Bahia. Campinas: Ed. da UNICAMP, 2007.

RAMOSE, Mogobe. A importância vital do "Nós". In: Revista do Instituto Unisinos Edição 353. São Leopoldo, 2010. 
SANTOS, Boaventura de Souza. Para além do pensamento abissal: das linhas globais a uma ecologia de saberes. In: SANTOS, Boaventura de Souza; MENESES, Maria Paula (Org.). Epistemologias do Sul. São Paulo: Ed. Cortez, 2010.

SANTOS, Juana Elbein dos. Os Nagô e a Morte. Petrópolis: Vozes, 1975.

SODRÉ, Muniz. O terreiro e a cidade: a forma social negro-brasileira. Petrópolis: Vozes, 1988.

SODRÉ, Muniz. Reinventando a Educação: diversidade, descolonização e redes.

Petrópolis: Vozes: 2012.

ZENÍCOLA, Denise Mancebo. Performance e Ritual: a dança das Iabás no Xirê. Rio de Janeiro: Mauad X; FAPERJ, 2014.

\section{SOBRE AS AUTORA:}

\section{Verônica Kimura}

Doutoranda em Educação, Universidade do Estado de Santa Catarina (UDESC) - Brasil; Programa de Pós-Graduação em Educação; Observatório de práticas escolares. Correio eletrônico: veronicakimura2020.com.br

(iD) https://orcid.org/0000-0002-1454-8152

\section{Geovana Mendonça Lunardi Mendes}

Pós-doutora em Educação, Arizona State University: Universidade do Estado de Santa Catarina (UDESC) - Brasil; Programa de Pós-graduação em Educação; Observatório de práticas escolares. Correio Eletrônico: geovana.mendes@udesc.br

(iD) https://orcid.org/0000-0002-8848-7436 